\title{
SUMMARY
}

\section{DETECTION OF SINGLET OXYGEN PRODUCTION AND ITS \\ RELATION TO PHOTOSYSTEM II PHOTODAMAGE IN INTACT \\ CYANOBACTERIA AND MICROALGAE}

Presented by

\author{
ATEEQ UR REHMAN \\ Supervisor: Dr. Imre Vass \\ Biological Research Center of the Hungarian Academy of Sciences \\ Institute of Plant Biology \\ Laboratory of Molecular Stress and Photobiology
}

Szeged May, 2016

\section{INTRODUCTION}

Reactive oxygen species (ROS) are produced primarily in the thylakoid bound photosynthetic complexes during the process of photosynthesis. Light energy absorbed by Chl molecules can 1) drive photosynthesis; 2) can be dissipated as heat, 3) re-emitted as red fluorescence. Light absorption by light harvesting chlorophylls in the light harvesting complex (LHCII) and in the PSII protein complex leads to excitation of the P680 reaction center Chl. The charge separation between the excited reaction center Chl assembly (P680*) and the pheophytin (Phe) molecule, i.e. the formation of the primary radical pair/charge separated state $\left(\mathrm{P} 680^{+*} \mathrm{Phe}^{-*}\right)$, is a primary event during photosystem II (PSII) electron transfer, which is further followed by rapid charge stabilization processes. 
Excited Chls in LHCII can be converted to triplet state $\left({ }^{3} \mathrm{Chl}\right)$, while triplet $\mathrm{P} 680$ can be formed during recombination of charge separated states. The interaction of excited triplet ${ }^{3} \mathrm{P} 680$ or ${ }^{3} \mathrm{Chl}$ with ground state triplet oxygen leads to the formation of singlet oxygen $\left({ }^{1} \mathrm{O}_{2}\right)$, which is a highly reactive species and capable of unhindered oxidation of various cellular components such as lipids, proteins, and nucleic acids, which ultimately can lead to cell death. ${ }^{1} \mathrm{O}_{2}$ can also damage the photosynthetic apparatus during stress conditions. Previous studies have shown that increased production of ${ }^{1} \mathrm{O}_{2}$ seems to occur primarily under high light stress conditions, which will ultimately result in the inactivation of PSII and photoinhibition. Previously the ${ }^{1} \mathrm{O}_{2}$ detection methods, such as fluorescent and electron paramagnetic resonance (EPR) sensors were developed to study ${ }^{1} \mathrm{O}_{2}$ formation in isolated PSII membranes and plant leaves, but methods for detection of ${ }^{1} \mathrm{O}_{2}$ in intact cyanobacteria and microalgae cells were largely unknown.

\begin{abstract}
AIMS
The general aim of the $\mathrm{PhD}$ work was to gain knowledge on the mechanisms of photodamage and photoprotection of the PSII complex in cyanobacteria and in dinoflagellates with special emphasis on the role of charge recombination reactions. The specific aims of this study were:
\end{abstract}

1. To develop a method for the detection of singlet oxygen $\left({ }^{1} \mathrm{O}_{2}\right)$ in intact cyanobacterial cells and to investigate the correlation of photodamage and the extent of ${ }^{1} \mathrm{O}_{2}$ production in WT Synechocystis as well as in mutants in which Gln130 residue of the D1 reaction center subunit of PSII is replaced with Glu or Leu.

2. To investigate the roles of ${ }^{1} \mathrm{O}_{2}$ in photoinhibition of Synechocystis $\triangle \operatorname{sig} C D E$, which contains the stress responsive SigB as the only functional group $2 \sigma$ factor.

3. To understand the role of orange carotenoid protein (OCP) as ${ }^{1} \mathrm{O}_{2}$ quencher by using mutants lacking, or overexpressing the OCP gene in Synechocystis.

4. To characterize ${ }^{1} \mathrm{O}_{2}$ production by a secondary metabolite of the cyanobacterium Nostoc XPORK14A.

5. To investigate the role of flavodiiron proteins (FDPs) in protecting against ${ }^{1} \mathrm{O}_{2}-$ dependent photodamage of PSII in Synechocystis.

6. To investigate the effect of moderate salt stress on ${ }^{1} \mathrm{O}_{2}$-dependent photodamage in Synechocystis mutants, which lack the Scp ABCDE small Chl binding proteins. 
7. To develop a method for the detection of ${ }^{1} \mathrm{O}_{2}$ in the dinoflagellate Symbiodinium and to study the correlation of inhibition of Calvin-Benson cycle by GA and $\mathrm{KCN}$ on the extent of photodamage under heat and light stress.

8. To investigate the effect of CAP-induced $\mathrm{O}_{2}{ }^{-}$production on the rate of photodamage in intact cyanobacterial cells.

\section{MATERIALS AND METHODS}

WT and mutant Synechocystis cells were cultured in BG-11 growth medium in a rotary shaker at $30{ }^{\circ} \mathrm{C}$ under a $3 \% \mathrm{CO}_{2}$-enriched atmosphere. The light intensity during growth was set to $40 \mu$ mole photons $\mathrm{m}^{-2} \mathrm{~s}^{-1}$. Cells in the exponential growth phase ( $\mathrm{A}_{580}$ of $\left.0.8-1\right)$ were used. The Chl concentration was determined by a UV-1601 (SHIMADZU) spectrophotometer after extracting the pigments with $100 \%$ methanol. Cells were harvested by centrifugation at $6500 \mathrm{~g}$ for $5 \mathrm{~min}$ and re-suspended in $100 \mathrm{~mL}$ of fresh BG-11 medium at concentration of $5 \mu \mathrm{g}$ of Chl per $\mathrm{mL}^{-1}$. The cells were kept under normal conditions for one hour before measurements. The CS-156 Symbiodinium cells were grown in artificial seawater at $26{ }^{\circ} \mathrm{C}$, and growth light intensity was $20 \mu$ mole photons $\mathrm{m}^{-2} \mathrm{~s}^{-1}$. Measurements were performed in cultures with approximately 10 $\mu \mathrm{g} \mathrm{Chl/mL}$.

${ }^{1} \mathrm{O}_{2}$ production in intact cells was detected by measuring the rate of light induced oxygen uptake in the presence of $5 \mathrm{mM}$ histidine (abbreviated as His). Synechocystis cells were centrifuged and re-suspended in fresh BG-11 medium before $\mathrm{O}_{2}$ uptake measurements, which were performed by using a Hansatech DW2 $\mathrm{O}_{2}$ electrode in the absence of artificial electron acceptors at $2300 \mu$ mole photons $\mathrm{m}^{-2} \mathrm{~s}^{-1}$ light intensity. Oxygen evolution was measured in the presence and absence of $5 \mathrm{mM}$ His and the difference between the oxygen rates was calculated. The rate of His-mediated oxygen uptake was used as a measure of ${ }^{1} \mathrm{O}_{2}$ production.

For photoinhibitory treatment of Synechocystis wild-type and mutants, the cell suspensions were illuminated at the irradiation of $500 \mu$ mole photons $\mathrm{m}^{-2} \mathrm{~s}^{-1}$ in the presence of the protein synthesis inhibitors lincomycin $(300 \mu \mathrm{g} / \mathrm{ml})$ or chloramphenicol $(200 \mu \mathrm{g} / \mathrm{ml})$, which block the protein synthesis dependent repair of PSII and allows determination of the rate of photodamage. Oxygen evolution was measured in the presence of $0.5 \mathrm{mM} \mathrm{DMBQ}$, as an artificial electron acceptor. Cell suspension of $2 \mathrm{~mL}$ at $5 \mu \mathrm{g} \mathrm{Chl} / \mathrm{mL}$ was used in each 
measurement, and three replicates were measured. Flash-induced increase and the subsequent decay of Chl fluorescence yield were measured by a double-modulation fluorometer (PSI Instruments, Brno) in the $150 \mu$ s to $100 \mathrm{~s}$ time range. The sample concentration was $5 \mu \mathrm{g}$ $\mathrm{Chl} / \mathrm{mL}$.

Singlet Oxygen Sensor Green (SOSG) reagent was used for ${ }^{1} \mathrm{O}_{2}$ imaging in cultured Symbiodinium Cells. SOSG was added to a culture of re-suspended Symbiodinium cells and imaging was performed by a confocal laser scanning microscope using excitation at $504 \mathrm{~nm}$ and emission detection at $525 \mathrm{~nm}$. The images were analyzed by using computer software from Leica. A Fluorescence Stereo Microscope (Leica Microsystem) was used for detection of ${ }^{1} \mathrm{O}_{2}$ production in cells free medium by using SOSG imaging.

\section{RESULTS}

\section{Development of method for the detection of ${ }^{1} \mathrm{O}_{2}$ production in Synechocystis sp. PCC 6803}

1) We have developed a method for ${ }^{1} \mathrm{O}_{2}$ detection in intact cyanobacteria by His-mediated chemical trapping (Rehman et al. 2013). The method is based on chemical trapping of ${ }^{1} \mathrm{O}_{2}$ by His, which leads to $\mathrm{O}_{2}$ uptake during illumination that can be detected and quantified by commercial oxygen electrodes. We have observed oxygen uptake in intact Synechocystis cells, during illumination in the presence of His. The His-mediated oxygen uptake effect was enhanced when the water content of the BG-11 culture medium was partly replaced with $\mathrm{D}_{2} \mathrm{O}$, which enhances the lifetime of ${ }^{1} \mathrm{O}_{2}$ and therefore facilitates its interaction with His. In contrast, the His-mediated oxygen uptake effect was suppressed by $\mathrm{NaN}_{3}$, which is ${ }^{1} \mathrm{O}_{2}$ quencher. Due to the limited mobility of ${ }^{1} \mathrm{O}_{2}$ these data demonstrate that exogenous $\mathrm{His}$ reaches close to the vicinity of ${ }^{1} \mathrm{O}_{2}$ production sites inside the cells, oxidized by ${ }^{1} \mathrm{O}_{2}$ and also that the His-mediated oxygen uptake assay can be used for ${ }^{1} \mathrm{O}_{2}$ detection in intact cells.

2) In a previous study the mechanism of charge recombination in PSII was investigated by using flash induced $\mathrm{Chl}$ fluorescence and thermoluminescence measurements in the D1Q130E and D1-Q130L mutants of Synechocystis 6803 showing an accelerated nonradiative recombination patway in the D1-Q130E mutant. We have found that this 
regulatory mechanism provides photo-tolerance in the Q130E mutant, which prevents the formation of triplet ${ }^{3} \mathrm{P} 680$ and ${ }^{1} \mathrm{O}_{2}$. Our results suggest that the differential photodamage of Q130E, wild type, and Q130L is correlated with the extent of ${ }^{1} \mathrm{O}_{2}$ production in these strains (Rehman et al. 2013). We investigated the roles of ${ }^{1} \mathrm{O}_{2}$ production with relation to the mechanisms of PSII photodamage and photoprotection in cyanobacteria and dinoflagellate by employing His-mediated oxygen uptake method.

\section{Applications of His-mediated $\mathrm{O}_{2}$ uptake method in Synechocystis mutants}

3) The His-mediated $\mathrm{O}_{2}$ uptake method was used to investigate the roles of oxidative stress and photoinhibition in high light acclimation using a regulatory mutant of the cyanobacterium Synechocystis. The mutant strain $\triangle$ sigCDE contains the stress responsive SigB as the only functional group $2 \sigma$ factor. We observed that $\Delta$ sigCDE suffers from oxidative stress in standard conditions. $\Delta$ sigCDE has high carotenoid and Flv4-2 contents and protected PSII against light induced damage, which is accompanied by more efficient ${ }^{1} \mathrm{O}_{2}$ quenching than in the control strain. Therefore, the decreased extent of photodamage in $\triangle \operatorname{sig} C D E$ mutant is correlated with suppressed rate of ${ }^{1} \mathrm{O}_{2}$ production (Hakkila et al. 2014).

4) We have employed the His-mediated $\mathrm{O}_{2}$ uptake method to characterize the properties of a secondary metabolite of Nostoc XPORK14A denoted as M22. This compound induced retardation of cell growth and inhibition of photosynthesis in Synechocystis cells, both in light and in darkness. We showed that M22 generates ${ }^{1} \mathrm{O}_{2}$ in the presence of light, which in turn affects the photosynthetic machinery of Synechocystis (Shunmugam et al. 2013).

5) The ${ }^{1} \mathrm{O}_{2}$ detection method was also used to study the role of flavodiiron proteins (FDPs) in PSII photoprotection. FDPs are specific electron transfer enzymes present mainly in anaerobic bacteria, and they are found also in cyanobacteria. Cyanobacterial FDPs constitute a specific group that evolved differently to cooperate with oxygenic photosynthesis. In Synechocystis there are four FDPs, Flv1-Flv4. Two of them, Flv2 and Flv4, are encoded by an operon together with the S110218 protein. We have shown that ${ }^{1} \mathrm{O}_{2}$ production is regulated by the amount of Flv2-4, and also that photodamage was correlated with the rate of ${ }^{1} \mathrm{O}_{2}$ production (Bersanini et al. 2014). 
6) The His-mediated $\mathrm{O}_{2}$ uptake method was used to understand the role of the orange carotenoid protein (OCP) in photoprotection of Synechocystis. The photoactive OCP has been shown to be essential in photoprotection as energy quencher. When OCP is photoactivated by strong blue-green light, it is able to dissipate excess energy as heat by interacting with phycobilisomes. We demonstrated that OCP protects Synechocystis cells from photodamage also by red light. We showed that this photoprotection is related to a decrease of ${ }^{1} \mathrm{O}_{2}$ concentration due to a scavenging action of OCP. Our results also showed that an OCP overexpressing mutant has higher resistance to photoinhibition and exhibits a decreased production of ${ }^{1} \mathrm{O}_{2}$. Altogether, the results showed that the OCP in Synechocystis is an efficient ${ }^{1} \mathrm{O}_{2}$ quencher and contributes to photoprotection (Sedoud et al. 2014).

7) The His-mediated $\mathrm{O}_{2}$ uptake method was employed to investigate the growth and photosynthetic activity of PSI-less and PSI-less/ScpABCDE- strains of Synechocystis under moderate salt stress conditions. Small CAB-like proteins (SCPs) are single-helix light-harvesting-like proteins found in all organisms performing oxygenic photosynthesis. We observed that the addition of $0.2 \mathrm{M} \mathrm{NaCl}$ to the growth medium in the PSIless/ScpABCDE ${ }^{-}$mutant strain decreased ${ }^{1} \mathrm{O}_{2}$ formation and induced resistance against photoinhibition compared to control strain (Tibiletti et al. 2016).

\section{Applications of the His-mediated $\mathrm{O}_{2}$ uptake method in dinoflagellate cells}

8) The His-mediated $\mathrm{O}_{2}$ uptake method was also employed with cultured Symbiodinium cells. We observed oxygen uptake in intact Symbiodinium cells and intact corals during illumination in the presence of His, which demonstrated the production of ${ }^{1} \mathrm{O}_{2}$. We observed that the production of ${ }^{1} \mathrm{O}_{2}$ in Symbiodinium cells was enhanced during thermal and light stress conditions, which was accompanied with photo-inactivation of PSII and ${ }^{1} \mathrm{O}_{2}$ production, while His itself provides protection against PSII photoinactivation and pigment bleaching. Therefore, the inactivation of PSII and enhanced production of ${ }^{1} \mathrm{O}_{2}$ by heat and light stresses promotes bleaching events in cultured Symbiodinium cells. We propose that ${ }^{1} \mathrm{O}_{2}$ induced inactivation of Symbiodinium cells may be involved in triggering the expulsion of Symbiodinium cells from the coral host, which leads to coral bleaching (Rehman et al. 2016c). 
9) We have also investigated the inhibition of the Calvin-Benson cycle by glycolaldehyde (GA) and potassium cyanide $(\mathrm{KCN})$ in cultured Symbiodinium cells to understand the role of Calvin-Benson cycle inhibition in coral bleaching. We showed that the inhibition of the Calvin-Benson cycle by GA did not induce coral bleaching without thermal stress, while $\mathrm{KCN}$ induce coral bleaching even without thermal stress and promote ${ }^{1} \mathrm{O}_{2}$ formation (Hill et al. 2014).

10) We have also detected ${ }^{1} \mathrm{O}_{2}$ production in cell free culture medium of Symbiodinium by His-mediated chemical trapping, demonstrating the excretion of ${ }^{1} \mathrm{O}_{2}$ sensitizing metabolite(s) from Symbiodinium cells (Rehman et al. 2016c).

\section{CAP mediated damage of Photosystem II via superoxide production in Synechocystis cells}

11) We tested the effect of CAP on the rate of photodamage in intact cyanobacterial cells. We have shown that $\triangle \mathrm{OCP}$ is more sensitive to high intensities of white light than wild type Synechocystis in the presence of lincomycin. However, in the presence of chloramphenicol the wild type and $\triangle \mathrm{OCP}$ show no differences in light sensitivity, which indicate that chloramphenicol induced PSII photoinhibiton by additional damage via the production of superoxide in intact Synechocystis cells (Rehman et al. 2016a).

His-mediated chemical trapping is a convenient and useful method for the detection of ${ }^{1} \mathrm{O}_{2}$ production in vivo. It has already been successfully applied in different cyanobacterial strains and dinoflagellate cells to characterize the intracellular production of ${ }^{1} \mathrm{O}_{2}$, and expected to find useful applications in other systems, as well. 


\section{KIVONAT}

${ }^{1} \mathrm{O}_{2}$ detektálása és a fénygátlásban játszott szerepének vizsgálata Synechocystis sp. PCC 6803 cianobaktériumban és Symbiodinium ostoros algában

A szinglet oxigén $\left({ }^{1} \mathrm{O}_{2}\right)$ az egyik legjelentősebb reaktív oxigénforma a fotoszintetikus rendszerekben. A ${ }^{1} \mathrm{O}_{2}$ triplett alapállapotú molekuláris $\mathrm{O}_{2}$ és triplett gerjesztett pigmentek, elsősorban a klorofill kölcsönhatása révén keletkezik a második fotokémiai rendszerben (PSII) és a fénygyüjtő komplexekben. Bár több módszer (úgy mint ESR és fluoreszcens spin csapdázás) is rendelkezésre áll a szinglet oxigén detektálására izolált fotoszintetikus rendszerekben, ezek nem alkalmazhatók élő cianobaktériumok és mikroalgák esetén, mivel a jelző molekulák nem képesek a sejtfalon áthatolni, ami hátráltatja a szinglet oxigén szerepének kutatását a fénygátlás folyamatában. Annak érdekében, hogy túllendüljünk ezen a nehézségen, kifejlesztettünk egy hisztidines kémiai csapdázáson alapuló módszert a ${ }^{1} \mathrm{O}_{2}$ detektálására intakt mikroalga sejtekben. A módszer lényege a ${ }^{1} \mathrm{O}_{2}$ kémiai megkötése hisztidin által, ami megvilágítás alatt, kereskedelmi forgalomban kapható oxigén elektródákkal detektálható $\mathrm{O}_{2}$ felvételhez vezet.

Fö eredmények:

\section{Szinglet oxigén képződés és fénykárosítás Synechocystis 6803-ban}

- Kimutattuk, hogy megvilágítás hatására hisztidin jelenlétében $\mathrm{O}_{2}$ felvétel figyelhető meg intakt Synechocystis sejtekben. Ez a jelenség felerősíthető a szinglet oxigén élettartamát megnövelő $\mathrm{D}_{2} \mathrm{O}$ jelenlétében, és lecsökkenthető a ${ }^{1} \mathrm{O}_{2}$ kioltó $\mathrm{NaN}_{3}$ segítségével. A szinglet oxigén behatárolt mobilitása miatt ezek az adatok azt mutatják, hogy a külső eredetü hisztidin eléri a szinglet oxigén képződés helyeit a sejten belül, tehát a hisztidin által közvetített $\mathrm{O}_{2}$ felvétel vizsgálat alkalmas élő sejtek szinglet oxigén termelésének detektálására.

- Korábbi vizsgálatok azt mutatták, hogy a második fotokémiai rendszer D1 reakciócentrum fehérjéit érintő D1-Q130E és D1-Q130L mutációk Synechocystis 6803ban befolyásolják a PSII sugárzás nélküli töltésrekombinációs folyamatait. Kimutattuk, hogy a D1-Q130E törzs esetén a felgyorsult sugárzás nélküli töltésrekombináció csökkenti a ${ }^{3}$ P680 és ezáltal a szinglet oxigén kialakulását és ezáltal fénykárosítás elleni védelmet biztosít, a D1-Q130L törzs esetén pedig az ellentétes hatás, azaz megnövekedett szinglet oxigén termelés és fénykárosítás következik be. Eredményeink azt mutatják, 
hogy a különböző mértékủ fénykárosodás korrelációban van a Q130E, vad típus, és Q130L vonalakban termelődő szinglet oxigén mennyiségével.

- A szinglet oxigén detektáló eljárást alkalmaztuk a flavodiiron proteinek (FLV) szerepének felderítésére a cianobakteriális PSII fényvédelmében. A Synechocystis-ben négyféle FLV-t találunk, Flv1-Flv4, amelyek specifikus elektrontranszport fehérjék. Közülük az Flv2 és Flv4 a PSII-böl az FLV1 és FLV3 a PSI-böl csatolnak ki elektronokat. Az eredményeink azt mutatták, hogy a szinglet oxigén fejlödés sebességét az Flv2-4 fehérjék növekvő mennyisége csökkenti, ami fénykárosodás mértékét is csökkenti.

- A hisztidin csapdázásos szinglet oxigén detektálási módszert alkalmaztuk a $\triangle \operatorname{sig} C D E$ Synechocystis mutáns fénykárosításának vizsgálatára. A mutáns vonal csak egyetlen kettes csoportba tartozó stressz reszponzív $\sigma$ factort (SigB) tartalmaz. Kimutattuk, hogy a $\Delta$ sigCDE törzs fokozott fénytoleranciával rendelkezik, ami a magas karotinoid és Flv4-2 tartalomnak, illetve az ennek következtében hatékonyabb szinglet oxigén kioltásnak köszönhető.

- A hisztidin-közvetített $\mathrm{O}_{2}$ felvétel módszerét alkalmaztuk a Nostoc XPORK14A egy másodlagos metabolitjának jellemzésére, amit M22-nek jelöltünk. Ez a vegyület növekedés és fotoszintézis gátlást okozott Synechocystis sejteken, mind fényben és sötétben. Kimutattuk, hogy az M22 fény hatására szinglet oxigént képez, ami viszont befolyásolja a Synechocystis fotoszintetikus rendszerét.

- A hisztidin csapdázásos szinglet oxigén detektálási módszert alkalmaztuk az OCP (orange carotenoid protein) fehérje szerepének vizsgálatára is a Synechocystis fényvédelemében. Kimutattuk, hogy az OCP jól ismert fényenergia disszipáló hatása mellett, nagyon hatékony szinglet oxigén kioltóként is müködik. Ennek következtében az OCP fehérje mennyiségétől függő szintű fényvédelmet biztosít olyan körülmények között is (pl. vörös fényben), amikor a fényenergia disszipációs mechanizmus nem müködik (amihez kék-zöld fény által kiváltott konformáció szükséges).

- A fenti módszert alkalmaztuk az ún. SCP klorofill kötő fehérjék szerepének vizsgálatában, amelyek minden oxigéntermelő fotoszintetikus szervezetben megtalálhatók. Korábbi eredmények azt mutatták, hogy az SCP fehérjék hiánya megnöveli a szinglet oxigén képződés ill. a fénykárosítás mértékét. Jelen munkánkban azt 
mutattuk ki, hogy $0.2 \mathrm{M} \mathrm{NaCl}$ hatására PSI-mentes/ScpABCDE mutáns esetében lecsökkentett a szinglet oxigén fejlődés mértéke és egyúttal növekedett fénykárosodással szemben tanúsított tolerancia.

\section{Szinglet oxigén képződés szimbiotikus ostoros algákban}

- A szinglet oxigén detektálási módszert a korall szimbiózisban a fotobionta szerepet játszó Symbiodinium ostoros alga sejteken is vizsgáltuk. Megfigyeltük a hisztidin által közvetített $\mathrm{O}_{2}$ felvételt megvilágítás alatt Symbiodinium sejteken és egész korallokon is, ami igazolta a szinglet oxigén fejlődés meglétét. A szinglet oxigén termelés sebessége felerősödött hő és fény stressz hatására, ami együtt járt a PSII fotoinaktivációjával. Ugyanakkor a hisztidin mint szinglet oxigén kioltó jelenléte részleges védelmet nyújtott a PSII fényindukált inaktiválása és a pigment károsodása ellen. Ezen eredmények alapján feltehető, hogy a szinglet oxigén által kiváltott sejtinaktiváció szerepet játszhat a Symbiodinium sejtek kilökődésében, ami korall pusztuláshoz vezet.

- Vizsgáltuk továbbá a Calvin-Benson ciklus glikolaldehiddel (GA) és kálium cianiddal (KCN) történő gátlásának hatását Symbiodinium sejteken, annak érdekében, hogy megértsük a Calvin-Benson ciklus szerepét a korall kifehéredésben. Az eredmények azt mutatták, hogy mind a GA mind a $\mathrm{KCN}$ jelenléte fokozza a szinglet oxigén termelést, de csak a KCN indukál korall kifehéredést.

- Igen lényeges eredményünk annak kimutatása is, hogy a Symbiodinium sejtek szinglet oxigén képződést érzékenyítő metabolitokat választanak ki a sejteken kívüli térbe, amelyek mennyisége megnő a korall pusztulást kiváltó fény- és hőstressz alatt. Ezek a metabolitok szerepet játszatnak a Symbiodinium sejtek és a korall polipok közötti szimbiózis szabályzásában.

\section{Kloramfenikol által indukált fénykárosítás Synechocystis sejtekben}

- Kimutattuk, hogy a protein szintézis gátlóként alkalmazott kloramfenikol szuperoxid képződéshez vezet és felerősíti a PSII fénygátlását Synechocystis-ban. Ez a hatás különböző mértékben érinti a vadtípusú és $\triangle \mathrm{OCP}$ mutáns sejteket és eltorzítja a valódi fénykárosításból származó hatásokat. Ezért a kloramfenikol szintézis gátlóként történő alkalmazását kerülni kell fotoinhibíciós vizsgálatokban. 


\section{LIST OF PUBLICATIONS (MTMT: 10037725)}

\section{Peer-reviewed publication, for PhD thesis:}

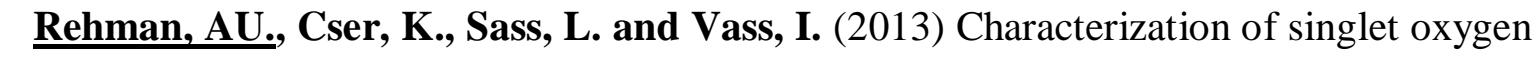
production and its involvement in photodamage of Photosystem II in the cyanobacterium Synechocystis PCC 6803 by histidine-mediated chemical trapping. Biochim Biophys Acta, 1827: 689-698. IF:4.66

> Shunmugam, S., Jokela, J.,Wahlsten, M., Battchikova, N., Rehman, AU., Vass I., Karonen, M., Sinkkonen, J., Permi, P., Sivonen, K., Aro, EM., and Allahverdiyeva, Y. (2013) Secondary metabolite from Nostoc XPORK14A inhibits photosynthesis and growth of Synechocystis PCC 6803. Plant Cell and Environment, 37: 1371-1381.IF:5.91

> Sedoud, A., Igual, RL, Rehman, AU., Wilson, A., Perreau, F., Boulay, C., Vass, I., Liszkay, AK. and Kirilovsky, D. (2014) Cyanobacterial photoactive Orange Carotenoid Protein is an excellent singlet oxygen quencher. Plant cell, 26: 1781-1791. IF:9.58

Hill, R., Szabó, M., Rehman, AU., Vass, I., Ralph, P. and Larkum, A. (2014) Inhibition of photosynthetic $\mathrm{CO}_{2}$ fixation in the coral Pocillopora damicornis and its relationship to thermal bleaching. Journal of Experimental Biology, 217: 2150-2162. IF:3.00

Bersanini,L., Battchikova,N., Jokel, M., Rehman, AU., Vass, I., Allahverdiyeva, Y. and Aro, EM. (2014) Flavodiiron protein Flv2/Flv4-related photoprotective mechanism dissipates excitation pressure of PSII in cooperation with phycobilisomes in cyanobacteria. Plant Physiology, 164: 805-818. IF:7.39

Hakkila, K., Antal, T., Rehman, AU., Wada, H., Vass, I., Tyystjärvi, E. and Tyystjärvi, T. (2014) Oxidative stress and photoinhibition can be separated in the cyanobacterium Synechocystis sp. PCC 6803. Biochim Biophys Acta, 1837: 217-225. IF:4.66

Rehman, AU., Szabó, M., Deák, Z., Sass, L., Larkum, A., Ralph, P. and Vass, I. (2016) Symbiodinium sp. cells produce light-induced intra- and extra-cellular singlet 
oxygen, which mediates photodamage of the photosynthetic apparatus and has the potential to interact with the animal host in coral symbiosis (Accepted in New Phytologist). IF: 7.67

\section{Other publications:}

1. Rehman, AU., Kodru, S., and Vass, I. (2016). Chloramphenicol mediates superoxide production in Photosystem II and enhances its photodamage in isolated membrane particles. Front. Plant Sci. 7:479. IF: 3.95

2. Vajravel, S., Kovács, L., Kis, M., Rehman, AU., Vass, I., Gombos, Z. and Toth, T. (2016) $\beta$-carotene influences the phycobilisome antenna of cyanobacterium Synechocystis sp. PCC 6803. Photosynth Res (in press). IF: 3.5

\section{Manuscripts in preparation}

i. Rehman, AU., Kodru, S. and Vass, I. (2016) Chloramphenicol induces photodamage of PII via superoxide production in intact Synechocystis cells (for $B B A$ ).

ii. Tibiletti,T., Rehman, AU., Vass,I. and Funk, C., (2015) Salt stress reveals a function in energy dissipation of the cyanabacterial smal $\mathrm{CAB}$ like proteins. (for $B B A$ ).

iii. Rehman, AU., Deák, Z. and Vass, I. (2014) Characterization of Superoxide and singlet oxygen production in isolated PSII membrane particles (for $B B A$ ).

iv. Rehman, AU., Szabó, M., Larkum, A., Ralph, P. and Vass, I. (2016) Peridinin carotenoid protein extracted from symbiodinium species is an excellent singlet oxygen quencher. (for Plant Cell). 


\section{International conference abstracts and poster presentations}

1. Rehman A, Deák Z, Larkum A, Ralph P and Vass I (2016) Singlet oxygen dependent photo-inactivation mechanism of PSII in intact microalgae. abstract of the school on Molecular and Biophysical aspects of Photosynthesis, (25-29 January, 2016) Venice, Italy

2. Kodru S, Rehman AU and Vass I (2015) How does chloramphenicol affect PSII photoinhibition in isolated spinach thylakoid membranes? abstract of the Straub conference, 3 June- 4 June 2015, Biological Research Center, Szeged, Hungary.

3. Vajravel S, Kis M, Rehman AU, Kodru S, Vass I, Gombos Z and Tóth T (2015)Does ßcarotene stabilize light harvesting antenna complexes of Synechocystis PCC 6803? abstract of the Straub conference, 3 June- 4 June 2015, Biological Research Center, Szeged, Hungary

4. Rehman AU, Deák Z, Larkum A, Ralph P and Vass I (2014) Production of singlet oxygen in cultured Symbiodinium cells, the photosyenthetic partner of the coral Pocillopora damicornis. Abstract of theInternational conferenceon Photosynthesis Research for Sustainability, 2 June- 7 June 2014, Pushchino, Russia.

5. $\underline{\text { Rehman AU }}$, Deák Z and Vass I (2013) Detection and characterization of singlet oxygen production in cultured Symbiodinium cells and its relation to coral bleaching"Abstract and poster of the International Conference on the Biophysics of Photosynthesis, 28 October -30 October 2013, Rome, Italy

6. Bersanini L, Battchikova N, Jokel M, Rehman AU, Vass I, Allahverdiyeva Y and Aro EM (2013) Flavodiiron proteins Flv4 and Flv2 co-operate with light-harvesting antenna to enhance PSII photoprotection in Synechocystis sp. PCC6803, Abstract of the $11^{\text {th }}$ Workshop on Cyanonbacteria, 7 August-10 August 2013, St.Louis, USA. pp- 33

7. Rehman AU, Deák Z and Vass I (2013)Characterization of superoxide and singlet oxygen production in isolated PSII membrane particles by using oxygen uptake 
measurements, Abstract of the International meeting on Photosynthesis Research for Sustainability" 5 June -9 June 2013, Baku, Azerbaijan.

8. Rehman AU, Sass L and Vass I (2013) Detection of singlet oxygen production in intact cyanobacteria by His-mediated chemical trapping, Abstract of the ESF-EMBO Symposium on Molecular bioenergetics of Cyanobacteria: Shaping the Environment, 15 April-20 April 2013, Polonia Castle in Pultusk, Poland.

9. Rehman AU, Deák Z and Vass I (2012) Detection of singlet oxygen in synechocystis sp. PCC 6803 and its relation to PSII photodamage. Abstract of the International's workshop on Photosynthesis from Science to Industry, 8 October- 12 October 2012, NH Conference Centre Leeuwenhorst in Noordwijkerhout, The Netherlands.

10. Rehman AU, Deák Z, Larkum A and Vass I (2012) Detection of singlet oxygen in cultured symbiotic dinoflagellate algae (genus Symbiodinium). Abstract of the ISPP 14 International Symposiums on Phototrophic Prokaryotes, 5 August -10 August 2012, Porto, Portugal.

\section{International conference- Oral presentations}

$\checkmark \underline{\text { Rehman A.U }}$ and Vass I. (2015). Detection of singlet oxygen production in intact microalgae" at a Photosynthesis meeting at Hungarian Academy of Sciences, 9 November 2015, Budapest, Hungary.

$\checkmark$ Rehman AU, Szabó M, Deák Z, Sass L, Larkum A, Ralph P and Vass I (2015). Characterization of Singlet oxygen dependent photo-inactivation mechanism of Photosystem II in cultured Symbiodinium cells and its involvement in coral bleaching. Abstract of oral presentation in a conference on Life Sciences Research, 4 Septermber-6 September 2015, Islamabad, Pakistan.

$\underline{\text { Rehman AU }}$, Sass L and Vass I (2015). Detection of singlet oxygen production in intact microalgae. Abstract of oral presentation in a Straub conference.3 June- 4 June 2015, Biological Research Center, Szeged, Hungary 
$\checkmark \underline{\text { Rehman AU }}$ (2013) Detection of singlet oxygen production in intact cyanobacteria by His mediated chemical trapping. Abstract of oral presentation in a Harvest final meeting, 18 Septermber-21 September 2013, Chania Crete, Greece.

$\checkmark \underline{\text { Rehman AU }}$ (2012) Detection of Singlet Oxygen production in Synechocystis sp. PCC 6803 and its Relation to PSII Photodamage. Abstract of oral presentation in an international workshop on "Photosynthesis: from Science to Industry" 08 October -12 October 2012, Leeuwenhorst in Noordwijkerhout, The Netherlands.

$\checkmark \underline{\text { Rehman AU }}$ (2012) Singlet oxygen production in microalgae and its relation to PSII photodamage. Abstract of oral presentation in a Harvest network meeting, 06-08 June, 2012, Kronlund, Sweden.

$\checkmark \underline{\text { Rehman AU }}$ (2012) Singlet oxygen production in microalgae and its relation to PSII photodamage. Abstract of oral presentation in an international meeting of Harvest young researchers, 15-18 March, 2012, Seville, Spain. 